\title{
KÊTHÉC
}

Jurnal Pengetahuan, Pemikiran dan Kajian Tentang Bunyi

Vol. 21, No. 2, November 2021, hal. 225-241

ISSN 1412-2065, eISSN 2714-6367

https://jurnal.isi-ska.ac.id/index.php/keteg

8) - -8

\section{PEMANFAATAN AUDIO RECORDING EQUIPMENT DALAM PEMBELAJARAN PRAKTIK INSTRUMEN REBAB, KENDANG DAN GENDER}

\author{
Wahyu Thoyyib Pambayun \\ Jurusan Karawitan, \\ Institut Seni Indonesia Surakarta, \\ Jl. Ki Hadjar Dewantara No 19 Kentingan, \\ Jebres, Surakarta (57126), Jawa Tengah, \\ Indonesia \\ wagamelan@gmail.com
}

dikirim 25 Februari 2022; diterima 25 Februari 2022; diterbitkan 01 Maret 2022

\begin{abstract}
Abstrak
Penelitian ini berjudul "Pemanfaatan Audio Recording Equipment dalam Pembelajaran Praktik Instrumen Rebab, Kendang dan Gender". Persoalan yang diurai dalam penelitian ini adalah bagaimana jenis audio recording equipment yang dapat digunakan dalam pembelajaran praktik instrumen rebab, kendang dan gender, bagaimana cara setting dan penggunaan audio recording equipment dan bagaimana cara memanfaatkan audio recording equipment dalam pembelajaran praktik instrumen rebab, kendang dan gender. Penelitian ini merupakan penelitian kualitatif yang menggunakan metode penelitian deskriptif analisis. Data dikumpulkan dengan cara observasi, studi pustaka dan wawancara. Teknik analisis data yang digunakan meliputi empat tahap, yaitu pengumpulan data, reduksi data, display data dan penarikan kesimpulan. Tujuan penelitian ini adalah memberikan rekomendasi jenis audio recording equipment yang dapat digunakan dalam pembelajaran praktik instrumen rebab, kendang dan gender, memberikan pemahaman tentang cara setting dan penggunaan audio recording equipment, serta memberikan pemahaman tentang cara pemanfaatan audio recording equipment dalam pembelajaran praktik instrumen rebab, kendang dan gender.
\end{abstract}

Kata Kunci: Audio, Recording, Pembelajaran, Rebab, Kendang, Gender

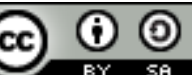

This work is licensed under a Creative Commons Attribution-ShareAlike 4.0

\begin{abstract}
This research is entitled "Utilization of Audio Recording Equipment in Practical Learning of Rebab, Kendang and Gender Instrument." The problems described in this study are: how are the types of audio recording equipment that can be used in learning the practice of fiddle, drum, and gender instrument, how to set and use audio recording equipment, and how to use audio recording equipment in learning the practice of fiddle, drums, and gender instrument. This research is qualitative research that uses descriptive analysis research methods. Data were collected by means of observation, literature study, and interviews. The data analysis technique used includes four stages: data collection, data reduction, data display, and concluding. The purpose of this study is to provide recommendations for types of audio recording equipment that can be used in learning the practice of fiddle, drum, and gender instrument, provide an understanding of how to set and use audio recording equipment, as well as provide an understanding of how to use audio recording equipment in learning the practice of the fiddle instrument. Drums and gender.
\end{abstract}

Key words: audio, recording, learning, rebab, kendang, gender 


\section{Pendahuluan}

Prinsip kebijakan pendidikan di masa pandemi covid-19 yang dikeluarkan oleh Kementerian Pendidikan dan Kebudayaan, Kementerian Agama, Kementerian Kesehatan, dan Kementerian Dalam Negeri yaitu "Kesehatan dan keselamatan peserta didik, pendidik, tenaga kependidikan, keluarga, dan masyarakat merupakan prioritas utama dalam menetapkan kebijakan pembelajaran". Atas dasar itu, Rektor ISI Surakarta membuat kebijakan yang tertuang pada: Keputusan Rektor Institut Seni Indonesia Surakarta Nomor 577/IT6.1/PP/2020 Tentang Panduan Penyelenggaraan Pembelajaran Semester Gasal Tahun Akademik 2020/2021 Institut Seni Indonesia Surakarta. Pada keputusan rektor tersebut dijelasakan bahwa pelaksanaan perkuliahan semester gasal tahun akademik 2020/2021 untuk mata kuliah teori masih dilakukan secara daring. Sementara, untuk mata kuliah praktik sedapat mungkin tetap dilakukan secara daring, namun jika menyangkut kelulusan dan kompetensi mahasiswa yang tidak dapat dilaksanakan secara daring, kegiatan tersebut dapat diselenggarakan secara luring dengan tetap mengutamakan kesehatan dan keselamatan mahasiswa, dosen, dan karyawan.

Menanggapi keputusan tersebut, penulis bersama tim pengajar mata kuliah praktik Karawitan Surakarta di Program Studi Seni Karawitan sepakat melaksanakan perkuliahan dengan menggunakan model hybrid learning. Hybrid learning merupakan perpaduan antara pembelajaran dalam jaringan (daring) dan luar jaringan (luring), perkuliahan sebagian dilakukan di kelas sebagian dilakukan melalui online (Sulistiono 2019). Pembelajaran dalam jaringan diterapkan pada awal pengenalan dan penjelasan materi, pemberian tutorial permainan instrumen melalui google meet dan youtube. Selain itu, pembelajaran dalam jaringan juga diterapkan pada saat ujian instrumen rebab, kendang dan gender. Mahasiswa mengirimkan video memainkan instrumen rebab, kendang dan gender kepada dosen melalui platform youtube dan whatsapp. Pembelajaran dalam jaringan ini juga berfungsi untuk memfasilitasi mahasiswa yang belum bisa datang ke kampus karena terkendala regulasi larangan perjalanan dan izin dari orang tua.

Pembelajaran luar jaringan diperuntukkan bagi mahasiswa yang dapat hadir di kampus. Fakta di lapangan yang dialami oleh penulis, menunjukkan bahwa jumlah mahasiswa yang dapat hadir untuk tatap muka langsung masih sangat sedikit dibandingkan dengan mahasiswa yang mengikuti pembelajaran secara daring. Padahal, pembelajaran daring untuk mata kuliah praktik terdapat banyak kendala. Salah satu kendala yang dihadapi adalah buruknya kualitas audio pada saat melakukan tatap muka melalui google meet. Pada saat pengajar memberikan contoh permainan instrumen tertentu, kualitas audio yang diterima oleh mahasiswa sangat tidak layak dan mengakibatkan mahasiswa tidak dapat menerima dan menirukan dengan baik.

Kualitas audio yang buruk disebabkan oleh perangkat yang digunakan. Dalam pembelajaran daring biasanya pengajar menggunakan hand phone atau laptop, padahal microphone yang ada pada handphone dan laptop mempunyai spesifikasi yang terbatas, tidak mampu untuk menangkap bunyi dari instrumen dengan jangkauan frekuensi tertentu. Selain itu, kualitas audio yang buruk disebabkan oleh perangkat yang digunakan untuk mendengarkan seperti: speaker handphone, earphone dan headphone tidak dapat menerima frekuensi bunyi instrumen tertentu. Contoh kasusnya adalah, proses pembelajaran daring instrumen gender. Instrumen gender mempunyai jangkauan frekuensi $100 \mathrm{~Hz}-4 \mathrm{Khz}$, sedangkan speaker handphone pada umumnya hanya mempunyai jangkauan frekuensi $250 \mathrm{~Hz}-2 \mathrm{Khz}$. Hal ini mengakibatkan bunyi instrumen gender pada jangkauan 100-250 Hz dan 2-4 Khz tidak dapat diterima oleh speaker handphone.

Wahyu Thoyyib Pambayun (Pemanfaatan Audio Recording Equipment Dalam Pembelajaran Praktik Instrumen Rebab, Kendang Dan Gender) 
Dampaknya mahasiswa tidak dapat mendengarkan bunyi instrumen gender secara utuh. Contoh yang lain, ketika mahasiswa merekam tugas memainkan instrumen tertentu, ia menggunakan microphone bawaan dari handphone, padahal kualitas microphone handphone sangat terbatas. Ketika tugas tersebut dikirimkan melalui youtube atau whatsapp kepada pengajar maka akan terjadi distorsi audio, pengajar tidak dapat mendengarkan hasil ujian dengan baik. Perlu disadari bahwa microphone bawaan dari handphone dan laptop memang tidak dirancang untuk merekam bunyi instrumen musik maupun gamelan dengan jangkauan frekuensi yang luas. Hal itu dapat dimaklumi karena merekam suara gamelan memang belum meluas atau belum menjadi bagian dari kurikulum pendidikan perekaman (Supanggah 2002).

Guna mengatasi masalah tersebut, diperlukan perangkat tambahan agar dapat menghasilkan kualitas audio yang baik. Perangkat tambahan yang dapat digunakan adalah perangkat rekam audio. Perangkat rekam audio dapat ditemui di studio musik, studio rekaman, studio broadcasting, tempat siaran radio dan televisi. Perangkat tersebut biasa disebut audio recording equipment. Audio recording equipment adalah sekumpulan perangkat keras (hardware) dan lunak (software) yang dirancang dan diintegrasikan untuk keperluan rekam audio (Shchugorev et al. 2020). Dahulu audio recording equipment merupakan perangkat eksklusif dan cukup mahal, hanya dimiliki oleh instansi penyiaran atau studio musik professional. Namun saat ini dengan perkembangan teknologi dan menjamurnya studio rekaman rumahan (home recording) serta banyaknya pilihan produk yang ada di pasaran, perangkat audio recording equipment dapat mudah didapatkan dengan harga yang terjangkau.

Pada penelitian ini, penulis berkeinginan memanfaatkan audio recording equipment untuk keperluan pembelajaran rebab, kendang dan gender. Penulis memilih instrumen rebab, kendang dan gender karena ketiga instrumen tersebut merupakan instrumen pokok yang harus dikuasai oleh mahasiswa Program Studi Seni Karawitan dan mendapatkan porsi besaran sks yang cukup banyak. Mengingat situasi pandemi ini belum dapat diketahui kapan akan berakhir, maka penelitian ini penting untuk dilakukan untuk meningkatkan kualitas pembelajaran daring sehingga proses transformasi ilmu pengetahuan di Program Studi Seni Karawitan dapat berjalan dengan baik. Penelitian ini dilakukan sebagai upaya untuk menerima kenyataan bahwa dunia sedang berubah dan akan terus berubah. Perubahan itu mengharuskan penulis untuk untuk bersiap diri dan beradaptasi, merespon dengan sikap dan tindakan sekaligus selalu belajar hal-hal baru.

Mengacu pada latar belakang diatas, permasalahan penelitian ini dapat dirumuskan sebagai berikut: 1) Jenis audio recording equipment seperti apa yang dapat digunakan dalam pembelajaran praktik instrumen rebab, kendang dan gender? 2) Bagaimana cara setting dan penggunaan audio recording equipment? 3) Bagaimana cara memanfaatkan audio recording equipment dalam pembelajaran praktik instrumen rebab, kendang dan gender?

\section{Metode}

Penelitian ini merupakan penelitian kualitatif yang menggunakan metode penelitian deskriptif analisis, adapun pengertian dari metode deskriptif analitis adalah suatu metode yang berfungsi untuk mendeskripsikan atau memberi gambaran terhadap objek yang diteliti melalui data atau sampel yang telah terkumpul sebagaimana adanya tanpa melakukan analisis dan membuat kesimpulan yang berlaku untuk umum (Sugiyono 2009). Dengan kata lain penelitian deskriptif analitis mengambil masalah atau memusatkan perhatian kepada masalah-masalah sebagaimana

Wahyu Thoyyib Pambayun (Pemanfaatan Audio Recording Equipment Dalam Pembelajaran Praktik Instrumen Rebab, Kendang Dan Gender) 
adanya saat penelitian dilaksanakan, hasil penelitian yang kemudian diolah dan dianalisis untuk diambil kesimpulannya.

\section{A. Tahapan Penelitian}

Penelitian yang berjudul "Pemanfaatan Audio Recording Equipment dalam Pembelajaran Praktik Instrumen Rebab, Kendang dan Gender" menggunakan tahapan-tahapan sebagai berikut:

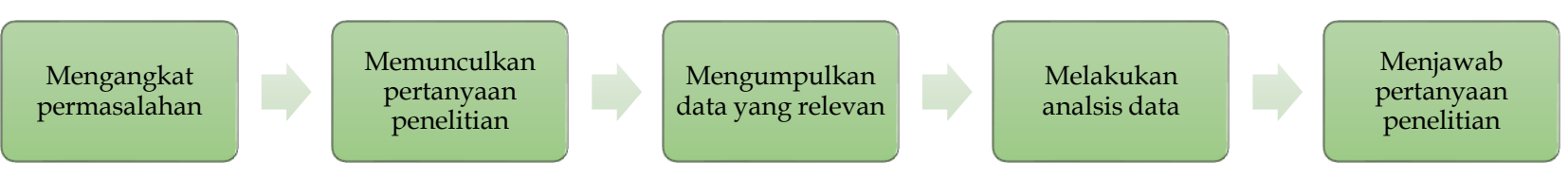

\section{B. Sumber Data}

Data-data yang digunakan untuk memecahkan masalah di dalam rumusan masalah-1 diambil dari:

1) Pustaka : Buku berjudul Practical Recording Techniques: The Step-by-step Approach to Professional Audio Recording (Bartlett 2017), buku berjudul Kitab Sakti Music Creator (Hardiman 2020), Artikel berjudul “Rancang Bangun Aplikasi Gamelan Gender Berbasis Android" (Dharma, Sudarma, and Suyadnya 2015), artikel berjudul "Imajiner Ruang Kepala Dalam Rekaman Gamelan Agêng Dengan Teknik Stereofonik" (Santosa 2021), artikel proseding berjudul "Desain Virtual Gamelan Jawa Sebagai Media Pembelajaran” (Pramudi and Budiman 2010), artikel berjudul "Aplikasi Pembelajaran Alat Musik Daerah Gamelan Jawa Berbasis Teknologi Realsense" (Pramanta, Rohman, and Kurniawan 2017)

2) Wawancara : Merwan Ardhi Nugroho selaku praktisi audio recording, Aloysius Suwardi selaku ahli organologi dan akustika gamelan.

Data-data yang digunakan untuk memecahkan masalah di dalam rumusan masalah-2 diambil dari:

1) Pustaka: Buku berjudul Practical Recording Techniques: The Step-by-step Approach to Professional Audio Recording (Bartlett 2017), buku berjudul Kitab Sakti Music Creator (Hardiman 2020), Buku berjudul The Art of Digital Audio Recording: A Practical Guide For Home And Studio (Savage 2011), artikel berjudul “Pengembangan Aplikasi Gamelan Selonding Berbasis Android" (Susila, Darmawiguna, and Sunarya 2015), buku berjudul "Modern Recording Techniques"(Huber and Runstein 2013), artikel berjudul "Multimedia Interaktif Pengenalan Gamelan Jawa "E-Gamel" Menggunakan Teknologi Augmented Reality" (Handayani and Nugraha 2017).

2) Observasi: Video berjudul "Membuat Studio Rekaman di Rumah \& Cara Pasang Alat-alatnya" di kanal youtube ArtSonica https://www.youtube.com/watch?v=qKOBzr2rjNw, video tutorial berjudul “Tutorial Focusrite 2i2 3 ${ }^{\text {rd }}$ Gen-Rekaman di HP, Cover Lagu Home Recording" di kanal youtube Laiqul https://www.youtube.com/watch?v=sgYrxiMmlu8. 


\section{KÊTî́G}

Jurnal Pengetahuan, Pemikiran dan Kajian Tentang Bunyi

3) Wawancara: Iwan Budi Santosa dan Merwan Ardhi selaku praktisi audio recording.

Data-data yang digunakan untuk memecahkan masalah di dalam rumusan masalah-3 diambil dari:

1) Pustaka : Artikel berjudul "Pembelajaran Karawitan Jawa Tingkat Dasar Berbasis Multimedia dalam Blended Learning" (Raharja 2019), artikel yang berjudul "Produksi Rekaman Karawitan RRI Yogyakarta Sebagai Bentuk Pelestarian Budaya" (Wahyono 2017), artikel Proseding yang berjudul “Pembelajaran Elecktronic Digital Music (Edm) Di Era-Milenial Pada Revolusi Industri 4.0"(Sumerjana 2019), artikel berjudul “Imajiner Ruang Kepala Dalam Rekaman Gamelan Agêng Dengan Teknik Stereofonik" (Santosa 2021), artikel berjudul “Media Informasi Interaktif Teknik Pukulan Pada Kendang Sunda Berbasis Multimedia" (Maulana and Kusno 2017), artikel berjudul "Aplikasi Mobile Apps Gamelan untuk Pembelajaran Seni" (Roekmana et al. 2020), artikel berjudu “Belajar Gamelan Jawa Menggunakan Platform iOS” (Kurniawanto, Sulistijono, and Kusuma W 2011)

2) Observasi: Video dengan judul "I.M. Harjito- Tutorial Gender Ladrang Pangkur" di kanal youtube Sumunar MN https://www.youtube.com/watch?v=2Q_9C2CJAJQ, video dengan judul "Darsono Hadiraharjo-Tutorial Rebab Gendhing Gambirsawit" di kanal youtube Sumunar MN https://www.youtube.com/watch?v=UBmDAJcoxVw.

3) Wawancara: Merwan Ardhi selaku praktisi audio recording, Aloysius Suwardi selaku ahli organologi dan akustika gamelan, Bambang Sosodoro selaku pengajar yang telah memanfaatkan alat rekam untuk kepentingan pembelajaran karawitan.

\section{Teknik Analisis Data}

Teknik analisis data yang digunakan meliputi empat tahap, yaitu pengumpulan data, reduksi data (penyederhanaan), display data (disajikan), dan verifikasi atau penarikan kesimpulan. Kemudian jika terdapat data-data yang bermasalah maka akan dilakukan uji keabsahan data menggunakan teknik triangulasi.

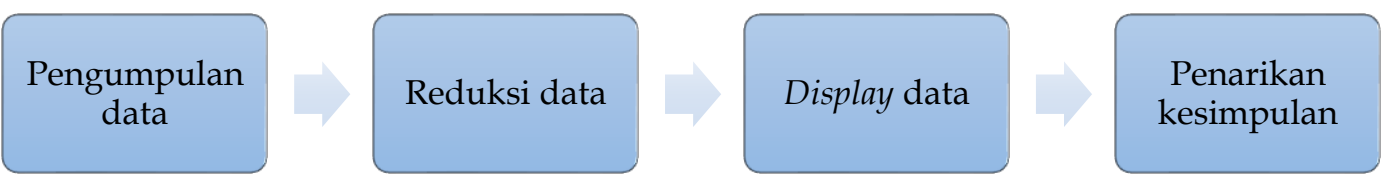

\section{Pembahasan}

Audio recording equipment adalah sekumpulan perangkat keras (hardware) dan lunak (software) yang dirancang dan diintegrasikan untuk keperluan rekam audio (Shchugorev et al. 2020). Jenis audio recording equipment dalam wujud perangkat keras diantaranya adalah: audio interface, microphone, speaker, headphone, midi controller. Sedangkan yang berwujud perangkat lunak adalah Digital audio workstation (DAW). DAW ini cukup banyak jenisnya, diantaranya Cubase, Nuendo, Studio One, Protools dan Logic Pro.

Berikut definisi dari beberapa alat diatas, Audio interface adalah alat yang digunakan untuk menangkap sinyal analog dari microphone atau instrumen music, kemudian mengubahnya menjadi sinyal digital yang dapat dibaca oleh computer atau laptop. Microphone adalah alat yang digunakan

Wahyu Thoyyib Pambayun (Pemanfaatan Audio Recording Equipment Dalam Pembelajaran Praktik Instrumen Rebab, Kendang Dan Gender) 


\section{KÊTTÉC}

untuk mengubah gelombang suara menjadi sinyal listrik. Speaker dan headphone adalah alat yang digunakan untuk mengeluarkan hasil bunyi. Digital audio workstation adalah software yang dapat digunakan untuk mengakomodasi rekaman, mixing, mastering dan/atau mengubah suara yang telah direkam (Wawancara Nugroho, 1 September 2021).

Hasil dari pengamatan video berjudul “Membuat Studio Rekaman di Rumah \& Cara Pasang Alat-alatnya” di kanal youtube ArtSonica, video tutorial berjudul “Tutorial Focusrite 2i2 3rd GenRekaman di HP, Cover Lagu Home Recording" di kanal youtube Laiqul, menunjukan cara memasang dan menggunakan audio recording equipment relatif mudah. Berikut gambar setting audio recording equipment.

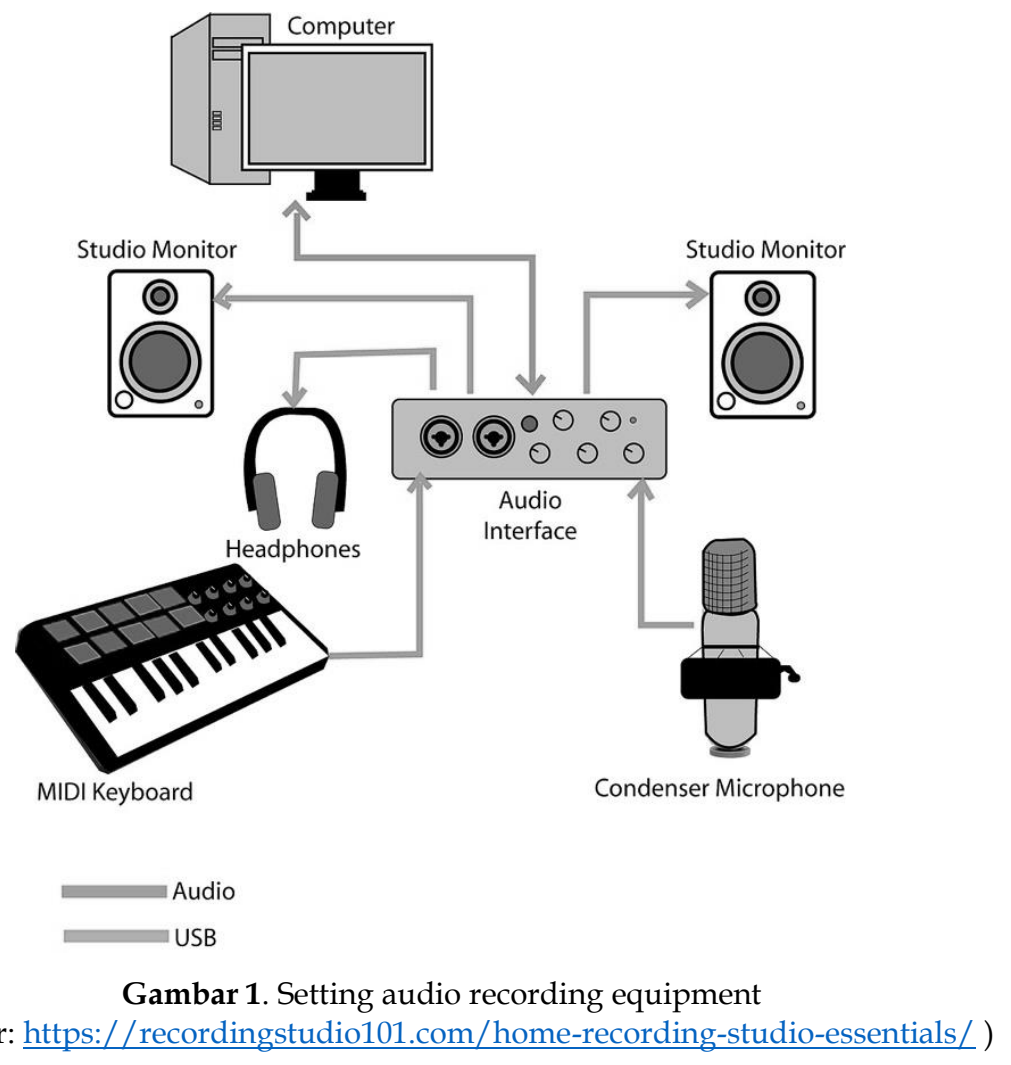

Audio Interface digunakan sebagai penghubung antara alat input dan output ke computer. Dalam gambar diatas, microphone dan midi digunakan sebagai alat input, kemudian headphone dan studio monitor sebagai outputnya. Sementara itu computer yang digunakan untuk mengolah semua datanya. Masing-masing alat menggunakan jenis kabel dan sambungan yang berbeda. Biasanya setiap audio interface memiliki petunjuk yang jelas untuk instalasi pemasangan. Dari audio interface ke computer/laptop menggunakan jenis sambungan USB, dari speaker/headphone ke audio interface menggunaka tipe TRS, dari microphone ke audio interface menggunakan tipe XLR, dari midi ke audio interface menggunakan tipe MIDI. Berikut jenis-jenis sambungan yang dimaksud. 


\section{Kîtî́C}

Jurnal Pengetahuan, Pemikiran dan Kajian Tentang Bunyi

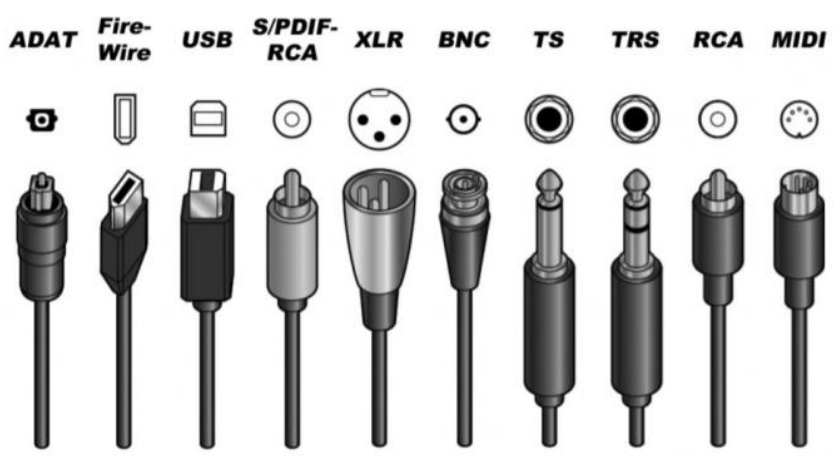

Gambar 2. Jenis-jenis sambungan

(Sumber: https://www.zealmusik.com/2019/08/20/jenis-kabel-audio/)

Selain melakukan pengamatan di kanal youtube, penulis juga melakukan observasi langsung di studio rekaman F Institut Seni Indonesia (ISI) Surakarta, cara settingnya hampir sama dengan yang ada di youtube, tetapi di Studio $\mathrm{F}$ ada tambahan menggunakan mixer digital. Berikut foto-foto pengamatan di studio $\mathrm{F}$.

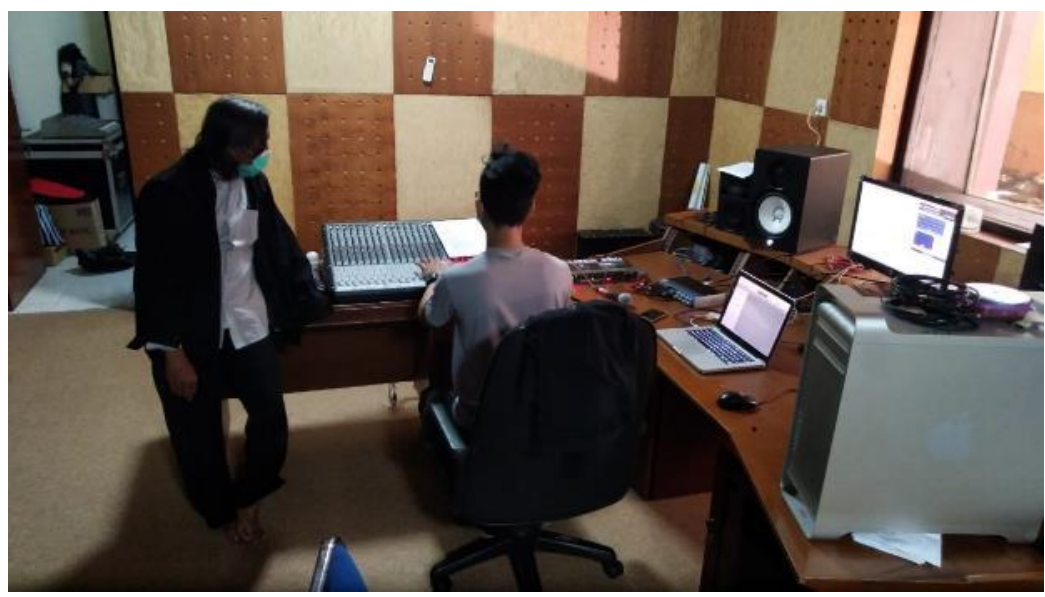

Gambar 3. Setup Alat Rekam di Studio F (Wahyu Thoyyib Pambayun, 2021)

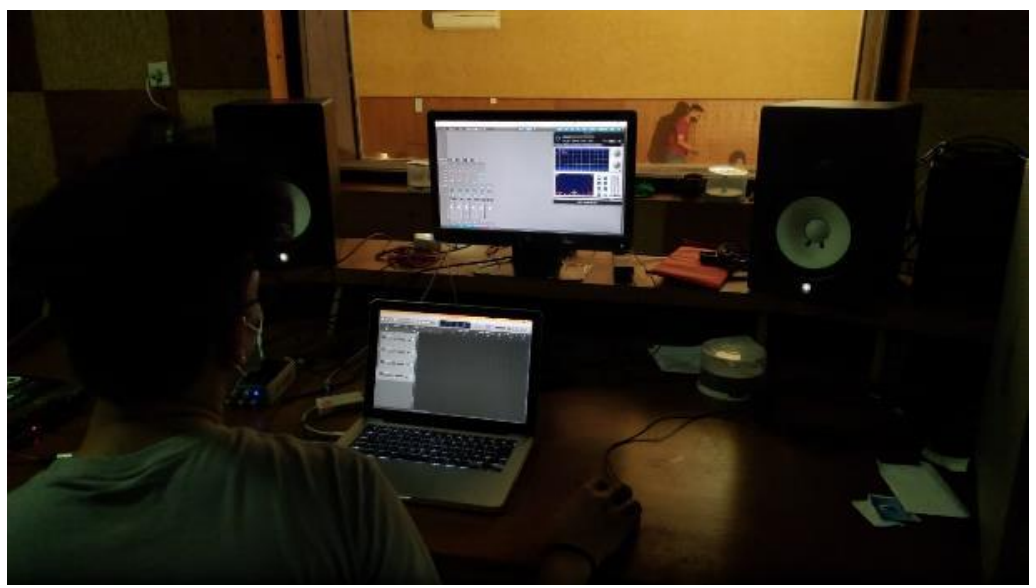

Gambar 4. Setup Alat Rekam di Studio F (Wahyu Thoyyib Pambayun, 2021) 
Alternatif cara setting yang berbeda

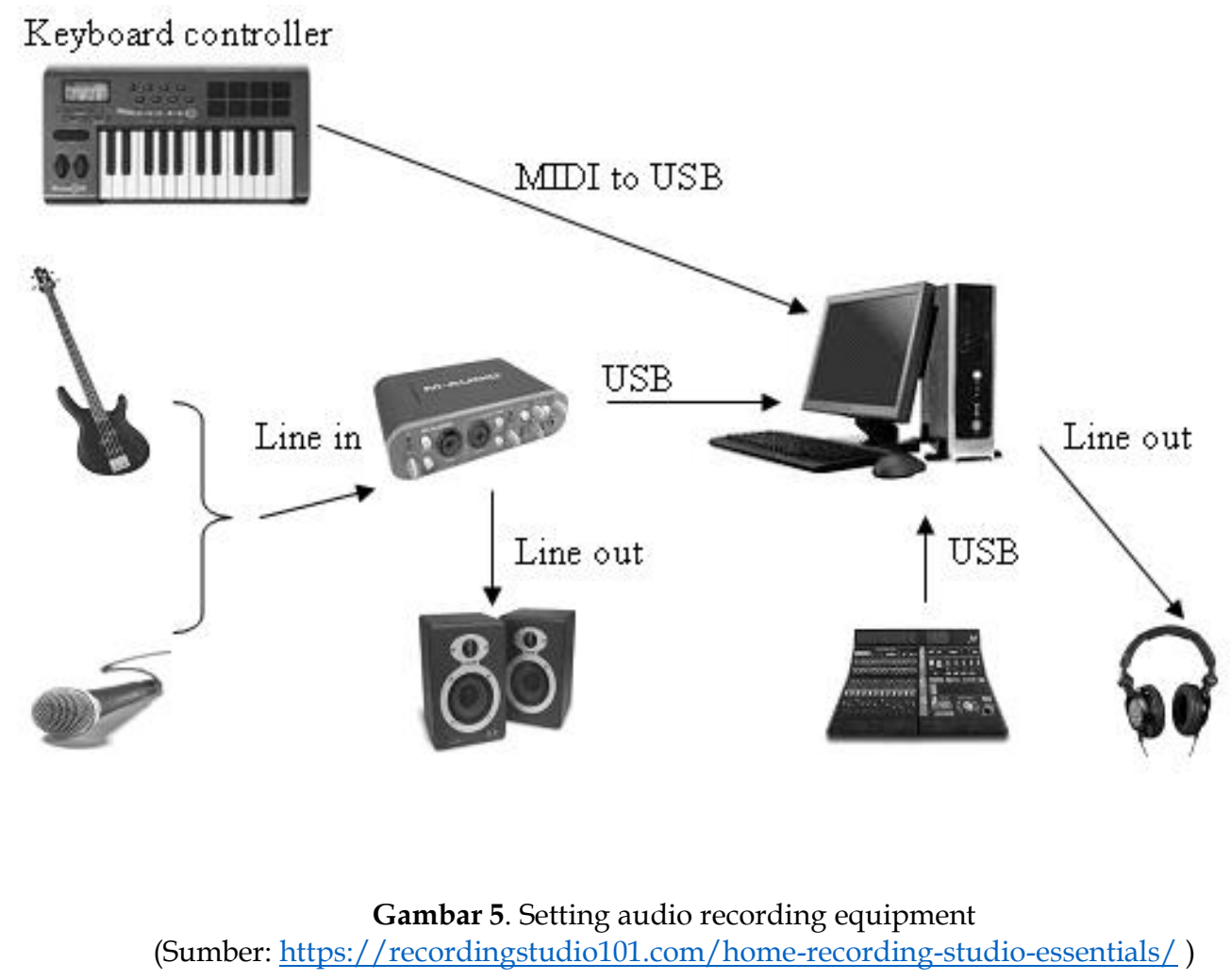

Setelah mengetahui jenis audio recording equipment dan mengetahui cara settingnya, langkah selanjutnya adalah mengamati audio recording equipment apa saja yang dapat digunakan dalam pembelajaran praktik instrumen rebab, kendang dan gender. Hasil dari pengamatan proses rekaman gamelan di Studio F dan video dengan judul "I.M. Harjito- Tutorial Gender Ladrang Pangkur", serta video dengan judul "Darsono Hadiraharjo-Tutorial Rebab Gendhing Gambirsawit" di kanal youtube Sumunar MN, penulis mendapatkan audio recording equipment apa saja yang dapat digunakan dalam pembelajaran praktik instrumen rebab, kendang dan gender. Alat-alat yang dibutuhkan adalah computer/laptop, audio interface, microphone, software DAW dan speaker/headphone. Midi controller dan mixer digital belum dibutuhkan dalam proses ini.

Setelah mengetahui alat-alat yang dibutuhkan, penulis kemudian mencari informasi mengenai spesifikasi yang tepat untuk pembelajaran praktik instrumen rebab, kendang dan gender. Berdasarkan pengamatan dan wawancara dengan Nugroho, didapatkan informasi spesifikasi dari alat-alat yang dibutuhkan.

Tabel 1. Alat dan Spesifikasinya

(Wahyu Thoyyib Pambayun, 2021)

\begin{tabular}{|l|l|l|}
\hline No & \multicolumn{1}{|c|}{ Alat } & \multicolumn{1}{c|}{ Spesifikasi } \\
\hline 1 & Laptop/Komputer & Minimal i5, ram 8 GB \\
\hline 2. & Audio Interface & Minimal 2 Channel, samplerate 48/24 \\
\hline 3. & Microphone & Condensor dan dynamic \\
\hline
\end{tabular}

Wahyu Thoyyib Pambayun (Pemanfaatan Audio Recording Equipment Dalam Pembelajaran Praktik Instrumen Rebab, Kendang Dan Gender) 


\begin{tabular}{|l|l|l|}
\hline 4. & Headphone & Tipe closed-back, bekarakter flat \\
\hline 5. & Speaker & Tipe monitor studio, ukuran 5 inch \\
\hline 6. & DAW & Free install \\
\hline
\end{tabular}

Dahulu audio recording equipment merupakan perangkat eksklusif dan cukup mahal, hanya dimiliki oleh instansi penyiaran atau studio musik professional. Namun saat ini dengan perkembangan teknologi dan menjamurnya studio rekaman rumahan (home recording) serta banyaknya pilihan produk yang ada di pasaran, perangkat audio recording equipment dapat mudah didapatkan dengan harga yang terjangkau.

Berikut link untuk pembelian alat-alat yang dimaksud:

Tabel 2. Alat dan Link Marketplace

(Wahyu Thoyyib Pambayun, 2021)

\begin{tabular}{|c|c|c|}
\hline No & Alat & Link Marketplace \\
\hline 1. & Audio Interface & $\begin{array}{l}\text { https://www.tokopedia.com/rekomendasi } / 162314 \\
\text { 4188?ref=googleshopping\&c=11973662787\&m=2425 } \\
\text { 63995\&p=1623144188\&txsc=google\&gclid=Cj0KCQi } \\
\text { A4b2MBhD2ARIsAIrcB- } \\
\text { T5ihzPaikhWwvqqccxrolb1TD13kRR987xHrToRV1S } \\
\text { UCp2B6QfkusaArVGEALw_wcB\&gclsrc=aw.ds }\end{array}$ \\
\hline 2. & Microphone Kondensor & $\begin{array}{l}\text { https://www.tokopedia.com/rekomendasi } / 197708 \\
\text { 7894?ref=googleshopping\&c=12507081355\&m=2844 } \\
\text { 11294\&p=1977087894\&txsc=google\&gclid=Cj0KCQi } \\
\text { A4b2MBhD2ARIsAIrcB- } \\
\text { QqZdcJcjBrFX5onaUI6EcER- } \\
\text { 14DtszJYHu2bt8QjNzX0NdbMc- } \\
\text { NZgaAjASEALw_wcB\&gclsrc=aw.ds }\end{array}$ \\
\hline 3. & Microphone Dinamik & $\begin{array}{l}\text { https:/ / www.tokopedia.com/rekomendasi } / 213376 \\
\text { 9180?ref=googleshopping\&c=14673914045\&m=2425 } \\
\text { 67817\&p=2133769180\&gclid=Cj0KCQiA4b2MBhD2 } \\
\text { ARIsAIrcB-Sw-BC- } \\
\text { ERd8qwiPgRVTRB9KlaQy6JPEvZSjRfJYB9WHQZ8 } \\
\text { Th-xxEoAaAikUEALw_wcB\&gclsrc=aw.ds }\end{array}$ \\
\hline 3. & Headphone & $\begin{array}{l}\text { https://shopee.co.id/ISK-HP680---Professional- } \\
\text { Closed-Back-Monitoring-Headphone- } \\
\text { i.10671590.127969686?gclid=Cj0KCQiA4b2MBhD2A } \\
\text { RIsAIrcB-R8nAyHXBc- } \\
\text { deeygbdRgKP5LIOrL8C8ohZzSroa7cJJUqTC1uZWt } \\
\underline{\text { YIaAswJEALw_wcB }}\end{array}$ \\
\hline 4. & Speaker & $\begin{array}{l}\text { https:/ / www.tokopedia.com/rekomendasi } / 215273 \\
\text { 4029?ref=googleshopping\&c }=11973662787 \& m=3634 \\
\text { 59198\&p=2152734029\&txsc=google\&gclid=Cj0KCQi } \\
\text { A4b2MBhD2ARIsAIrcB- }\end{array}$ \\
\hline
\end{tabular}

Wahyu Thoyyib Pambayun (Pemanfaatan Audio Recording Equipment Dalam Pembelajaran Praktik Instrumen Rebab, Kendang Dan Gender) 


\section{KÊTẾC}

Jurnal Pengetahuan, Pemikiran dan Kajian Tentang Bunyi

\begin{tabular}{|l|l|l|}
\hline & $\begin{array}{l}\text { ROU75MFA3pJMPqPkMzVk008ulff7mY_hBR0iO7R } \\
\text { f7hcFfGFc4YJwAaAsZJEALw_wcB\&gclsrc=aw.ds }\end{array}$ \\
\hline
\end{tabular}

Salah satu faktor yang cukup penting untuk mendapatkan hasil yang maksimal adalah penempatan microphone, penulis melakukan pengamatan dan percobaan, berikut beberapa foto penempatan microphone untuk instrumen rebab, kendang dan gender.

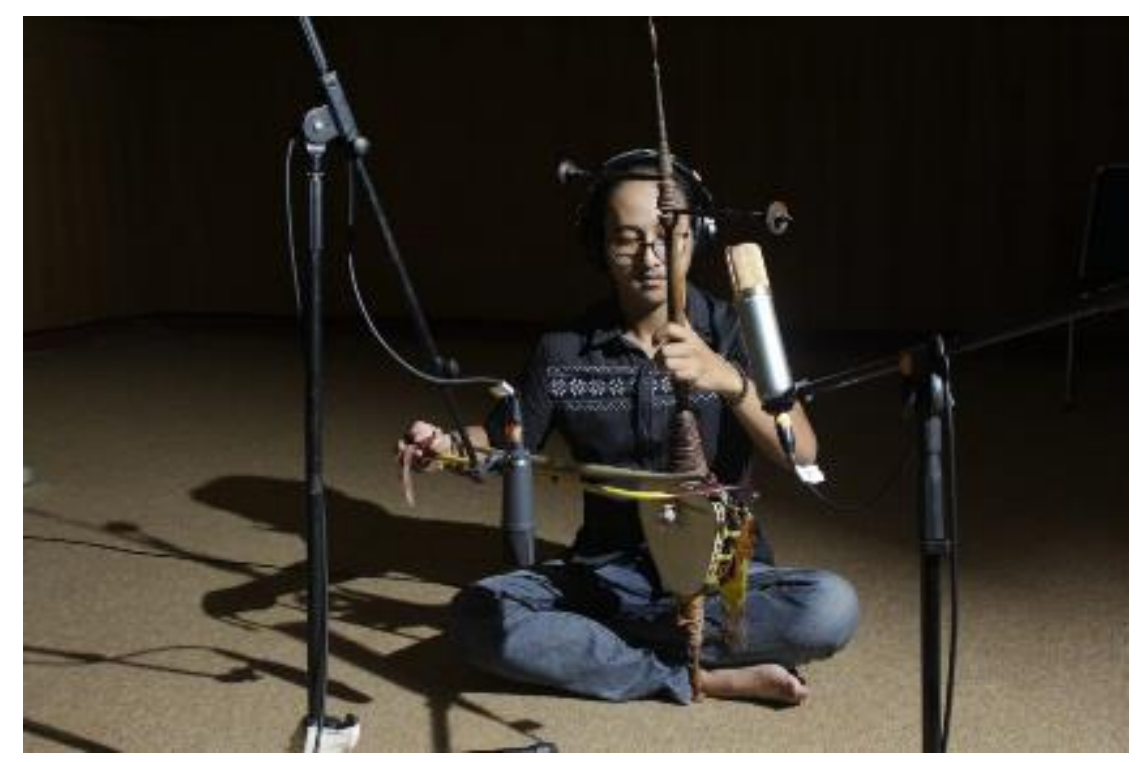

Gambar 5. Penempatan microphone untuk rebab (Wahyu Thoyyib Pambayun, 2021)

Pada perekaman instrumen rebab menggunakan 2 microphone jenis kondensor, microphone yang berada di bawah untuk menangkap suara membrane dan gesekan kosok dengan kawat, kemudian microphone yang diatas untuk merekam suara pidakan jari.

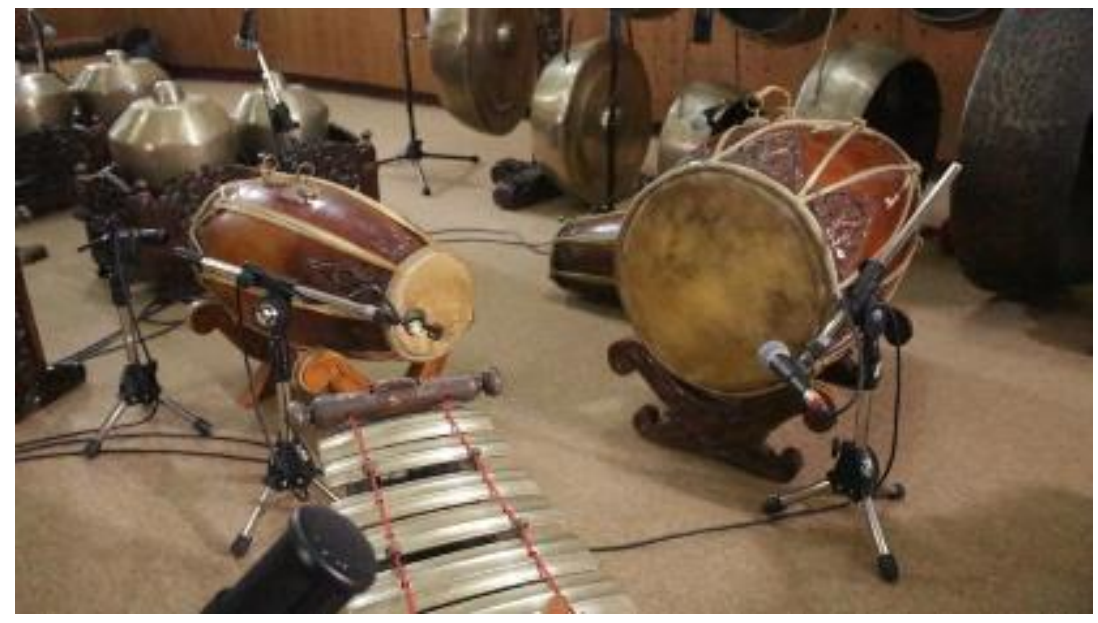

Gambar 6. Penempatan microphone untuk kendang (Wahyu Thoyyib Pambayun, 2021) 


\section{KÊTẾC}

Jurnal Pengetahuan, Pemikiran dan Kajian Tentang Bunyi

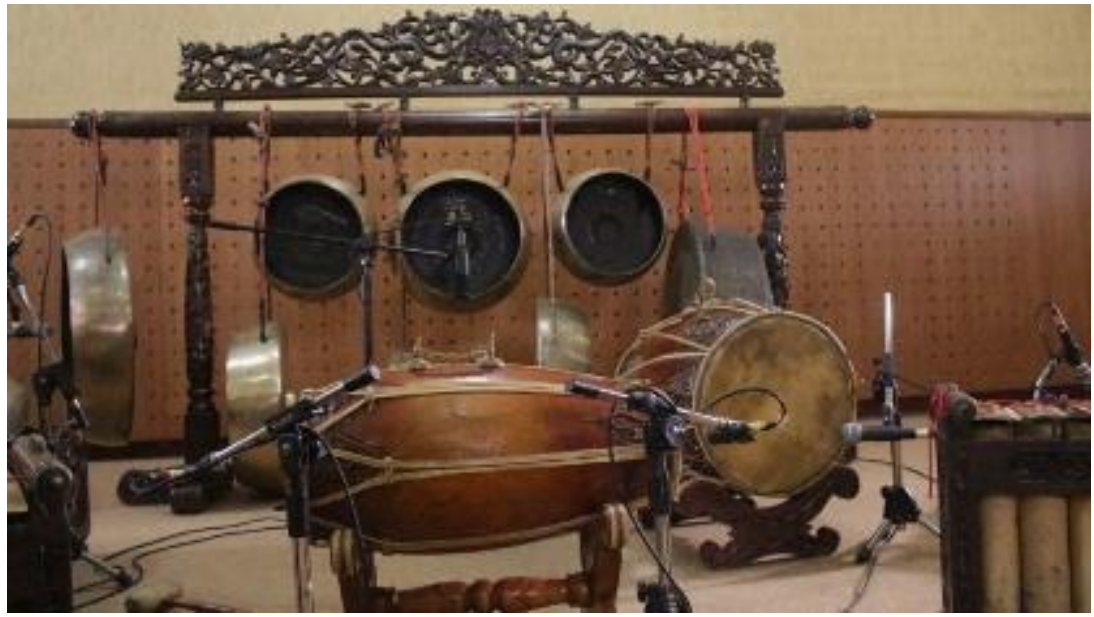

Gambar 7. Penempatan microphone untuk kendang (Wahyu Thoyyib Pambayun, 2021)

Perekaman instrumen kendang, menggunakan 3 microphone berjenis dinamik, microphone ditempatkan di masing-masing tebokan, jarak antara tebokan dengan microphone dinamik diusahakan kurang lebih $10 \mathrm{~cm}$. Cara ini cukup efektif untuk mendapatkan hasil yang natural.

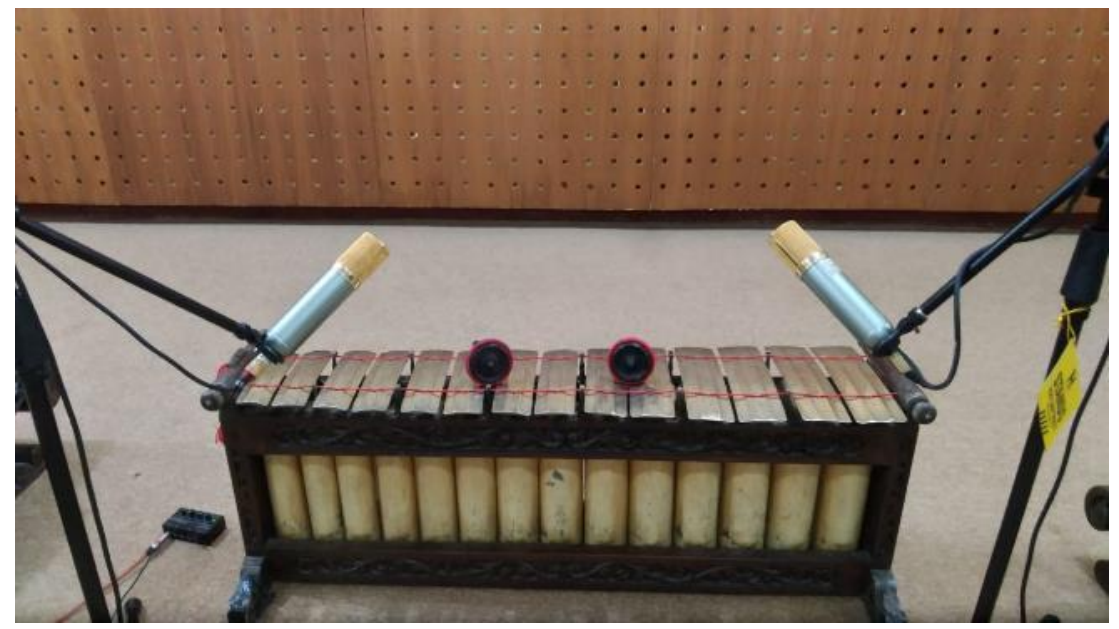

Gambar 8. Penempatan microphone untuk gender

(Wahyu Thoyyib Pambayun, 2021)

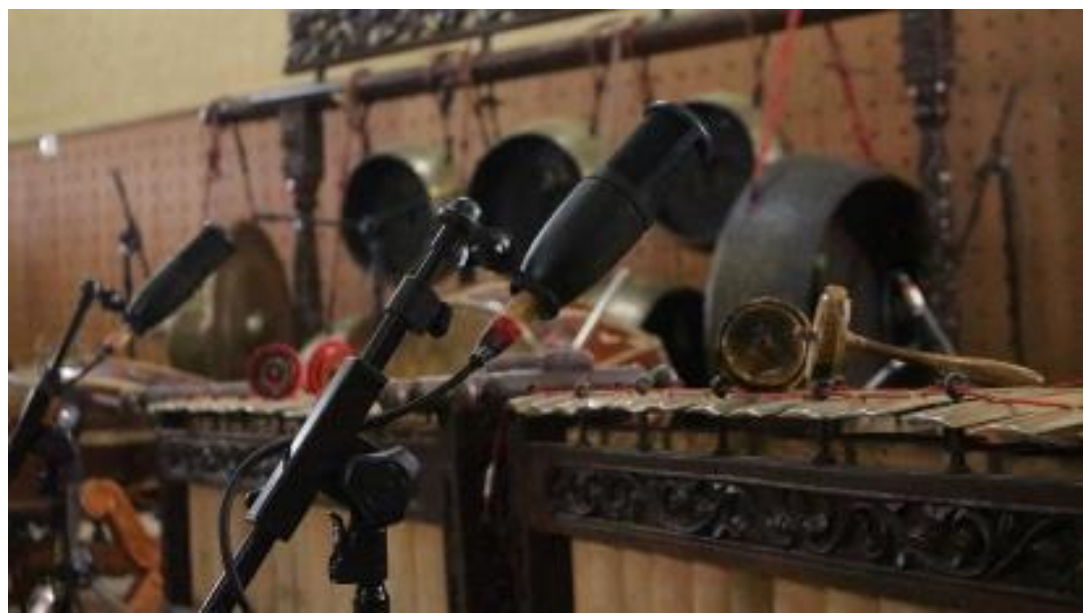

Gambar 9. Penempatan microphone untuk gender (Wahyu Thoyyib Pambayun, 2021)

Wahyu Thoyyib Pambayun (Pemanfaatan Audio Recording Equipment Dalam Pembelajaran Praktik Instrumen Rebab, Kendang Dan Gender) 


\section{KÊTTÉC}

Instrumen gender memiliki resonator berupa tabung yang dikalangan pengrawit lazimnya disebut bumbungan yang berfungsi memperkeras atau memperlantang suara yang dihasilkan dari bilah (Purwanto 2020). Oleh karena itu posisi microphone dalam menangkap bunyi dari bilah dan resonator harus dipertimbangkan. Perekaman instrumen gender menggunakan 2 cara, gambar yang diatas menggunakan 2 microphone kondensor ditempatkan di bilah kanan dan kiri dengan jarak antara instrumen dan microphone cukup jauh, kemudian gambar 2 menggunakan 1 kondensor ditempatkan di bilah bagian tengah tetapi dengan jarak yang cukup dekat. Kedua cara diatas samasama mampu menghasilkan rekaman yang baik.

Setelah mengetahui cara setting dan penempatan microphone untuk merekam instrumen rebab, kendang dan gender, selanjutnya penulis mencari informasi cara memanfaatkan audio recording equipment dalam pembelajaran praktik instrumen rebab, kendang dan gender. Penulis melakukan wawancara kepada Sosodoro, selaku pengajar yang telah memanfaatkan audio recording equipment untuk pembelajaran gamelan. Audio recording equipment dapat dimanfaatkan untuk 1) Merekam tutorial memainkan gamelan kemudian diunggah ke youtube atau googledrive, 2) Merekam tutorial secara real time pada pada saat pembelajaran daring melalui googlemeet ataupun zoom (Wawancara Sosodoro, 16 September 2021).

Langkah awal untuk mengintegrasikan audio recording equipment digabungkan dengan aplikasi zoom adalah memastikan laptop/computer mendeteksi perangkat audio interface.

Buka system preference-kemudian pilih ikon sound

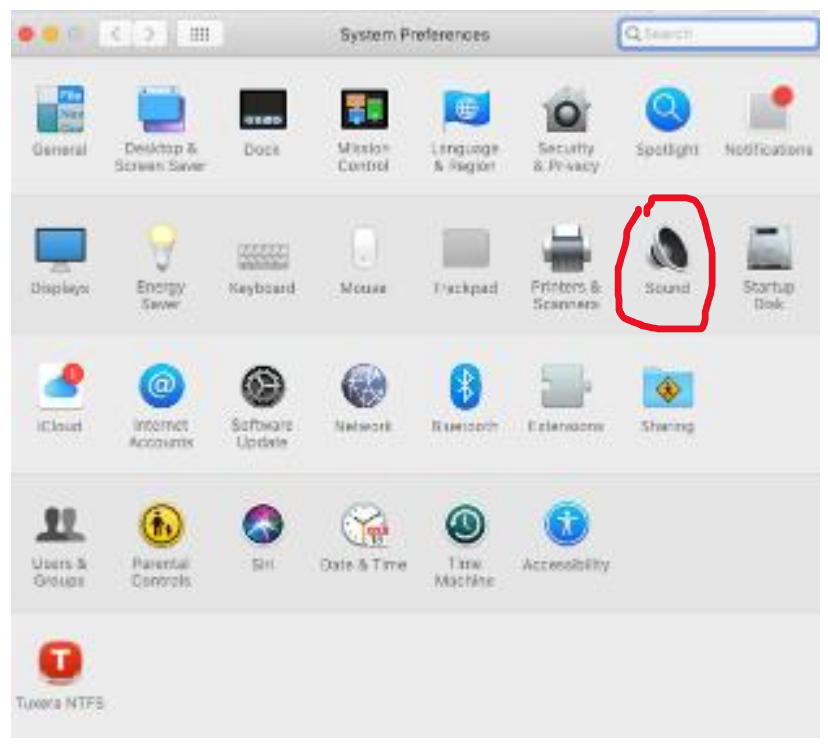

Gambar 10. Menu system preference

(Wahyu Thoyyib Pambayun, 2021) 
Jadikan perangkat audio interface sebagai input dan outputnya

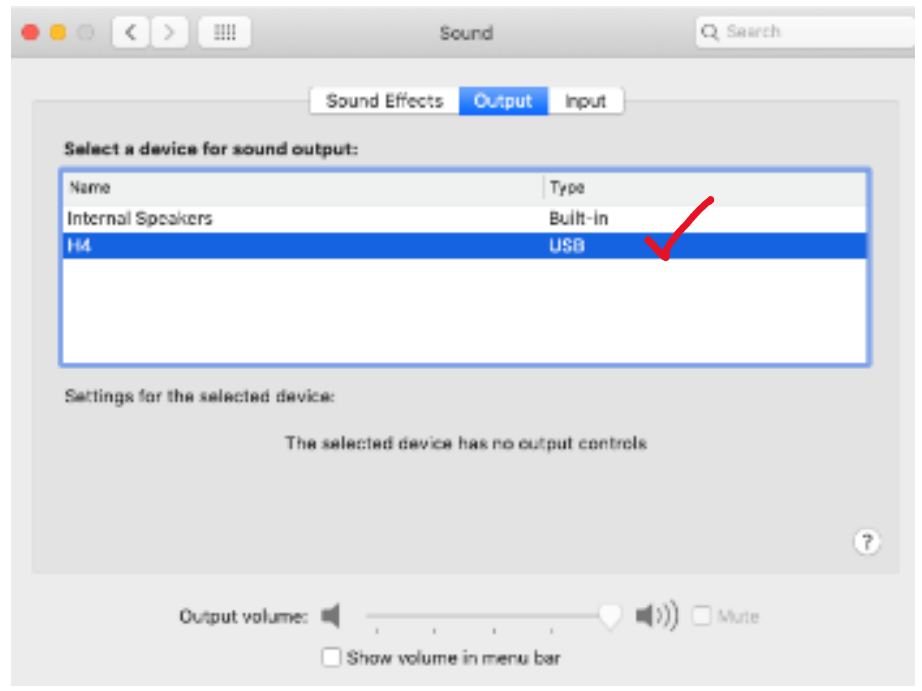

Gambar 11. Menu sound

(Wahyu Thoyyib Pambayun, 2021)

setelah itu sinkronkan aplikasi zoom meeting dengan audio recording equipment

Buka zoom meting-kemudian buka preference-pilih pada menu audio

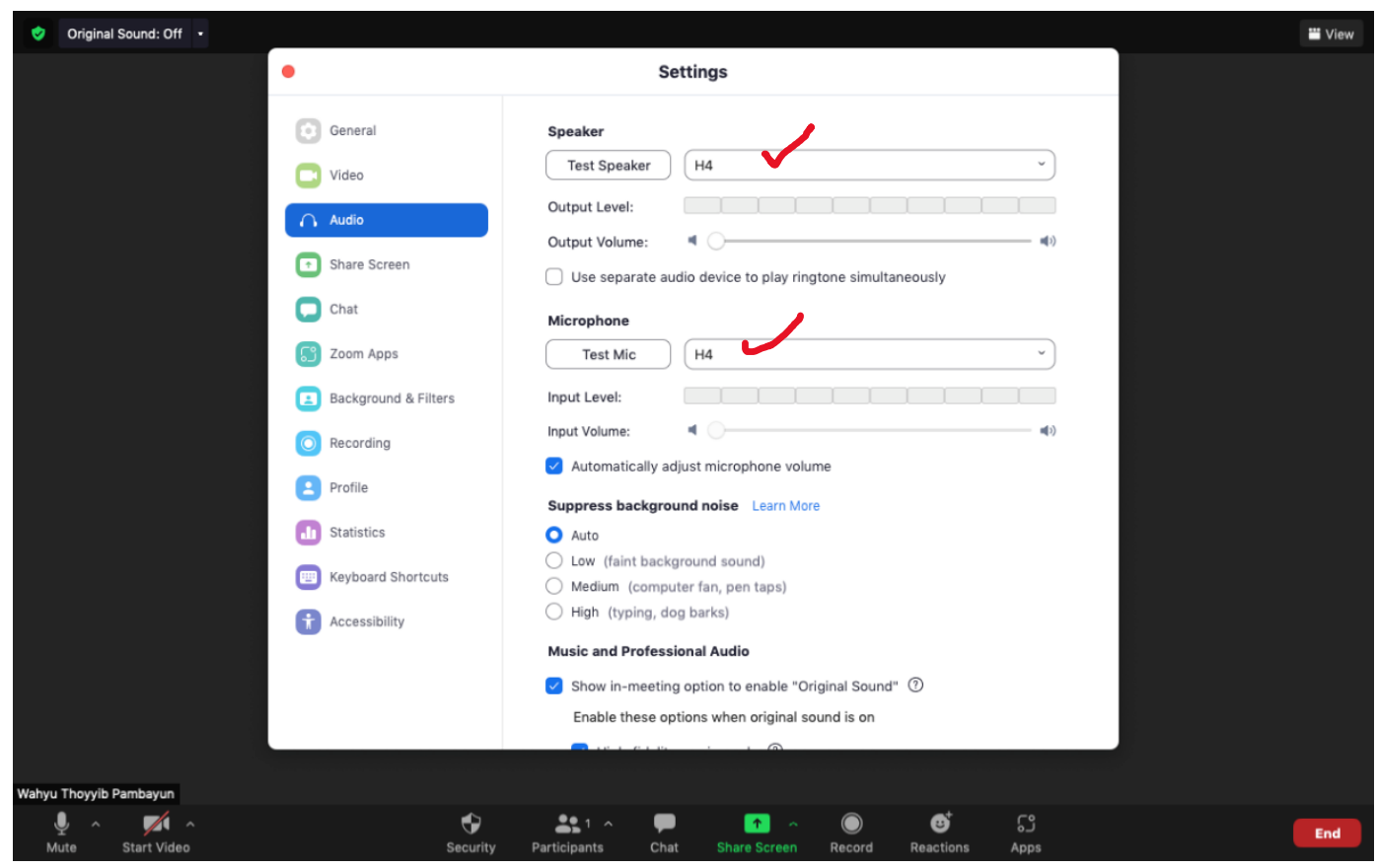

Gambar 12. Menu settings pada zoom

(Wahyu Thoyyib Pambayun, 2021)

Pastikan audio interface menjadi pilihan speaker dan microphone

Kemudian aktifkan fitur original sound di aplikasi zoom, berikut stepnya:

A.Untuk mengaktifkan fitur original sound desktop client

Wahyu Thoyyib Pambayun (Pemanfaatan Audio Recording Equipment Dalam Pembelajaran Praktik Instrumen Rebab, Kendang Dan Gender) 


\section{KÊTTÉC}

Jurnal Pengetahuan, Pemikiran dan Kajian Tentang Bunyi

Sign in ke Zoom desktop client.

Pada Home tab, click settings button.

Click Audio tab.

Periksa pada bagian Show in-meeting option to "Enable Original Sound" from microphone.

(Optional) Check High fidelity music mode.

(Optional) Uncheck Echo cancellation.

(Optional) Check Stereo audio.

Aplikasi zoom di handphone

Sign out and sign back in to the Zoom mobile app.

Tap Settings.

Tap Meetings.

Tap the toggle to enable Use Original Sound.

B. Mengaktifkan original sound didalam meeting Desktop client

Sign in to the Zoom desktop client.

Start or join a meeting. klik fitur original Sound di pojok kiri.

(Optional) Click the to the right of the Original Sound option to select a microphone that automatically uses original sound when selected.

Aplikasi zoom di handphone

Sign in to the Zoom mobile app.

Start or join a meeting.

Tap the ... More icon.

Tap Enable Original Sound.

Wahyu Thoyyib Pambayun (Pemanfaatan Audio Recording Equipment Dalam Pembelajaran Praktik Instrumen Rebab, Kendang 


\section{KÊTẾC}

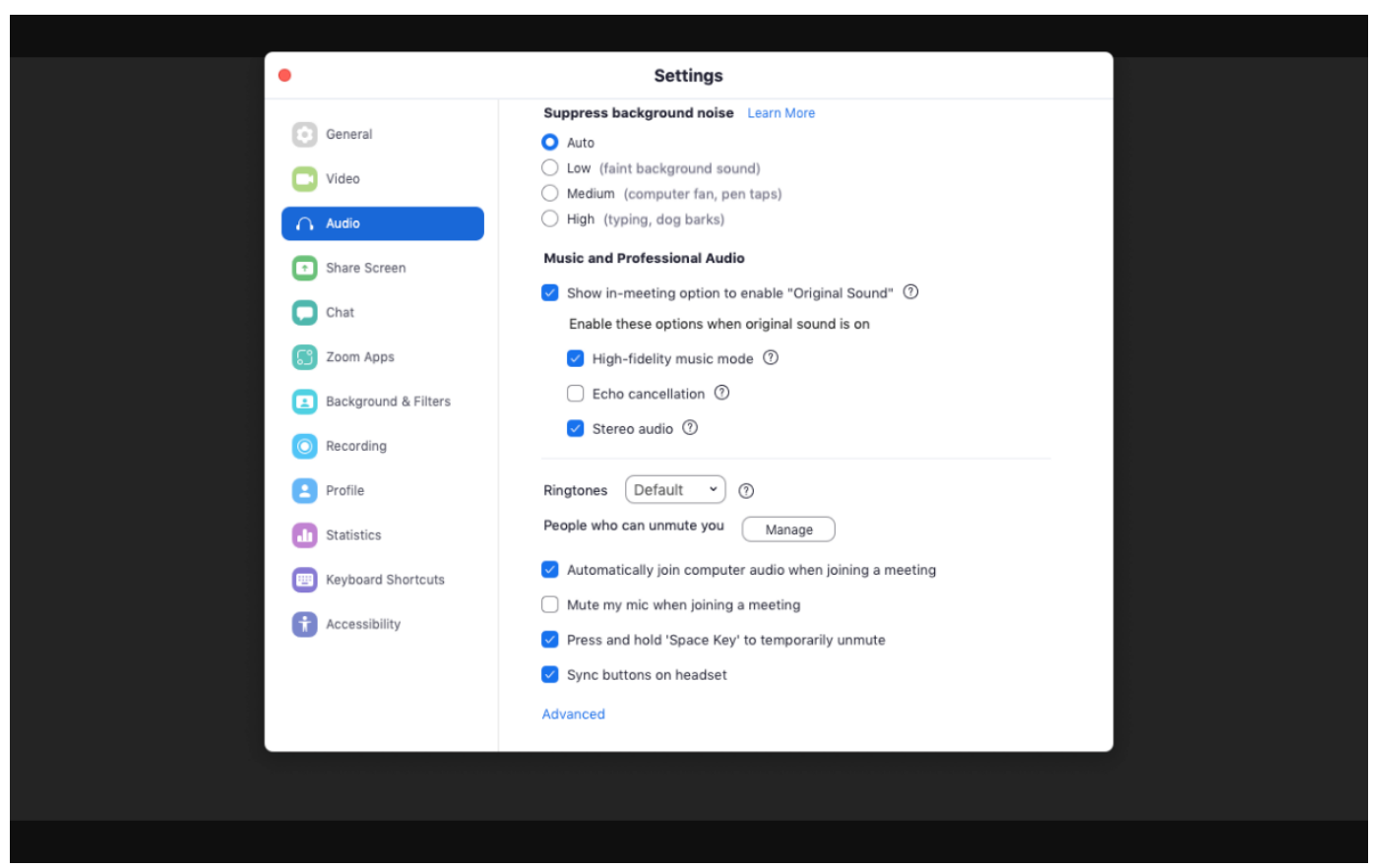

Gambar 13. Menu settings pada zoom

(Wahyu Thoyyib Pambayun, 2021)

Atur setingan seperti gambar diatas.

Jika mengikuti petunjuk dengan benar, maka perangkat audio recording equipment sudah terintegrasi dengan aplikasi zoom, kemudian dapat dengan real time digunakan untuk merekam instrumen rebab, kendang dan gender pada saat perkuliahan dalam jaringan (daring).

\section{Kesimpulan}

Dahulu audio recording equipment merupakan perangkat eksklusif dan cukup mahal, hanya dimiliki oleh instansi penyiaran atau studio musik professional. Namun saat ini dengan perkembangan teknologi dan menjamurnya studio rekaman rumahan (home recording) serta banyaknya pilihan produk yang ada di pasaran, perangkat audio recording equipment dapat mudah didapatkan dengan harga yang terjangkau.

Jenis audio recording equipment yang dapat digunakan dalam pembelajaran praktik instrumen rebab, kendang dan gender diantaranya: adalah computer/laptop, audio interface, microphone, software DAW dan speaker/headphone.

Salah satu faktor penting untuk mendapatkan hasil perekaman yang maksimal adalah penempatan microphone. Audio recording equipment dapat dimanfaatkan untuk 1) Merekam tutorial memainkan gamelan kemudian diunggah ke youtube atau googledrive, 2) Merekam tutorial secara real time pada pada saat pembelajaran daring melalui googlemeet ataupun zoom. 


\section{Daftar Pustaka}

Bartlett, Bruce. 2017. Practical Recording Techniques: The Step-by-Step Approach to Professional Audio Recording. 7th ed. New York an London: Routledge Taylor \& Francis Group.

Dharma, Nyoman Swastika, Made Sudarma, and Made Arsa Suyadnya. 2015. "Rancang Bangun Aplikasi Gamelan Gender Berbasis Android." E-Journal SPEKTRUM 2 (2): 18-23.

Handayani, Endah, and Bhanu Sri Nugraha. 2017. "Multimedia Interaktif Pengenalan Gamelan Jawa 'E-Gamel' Menggunakan Teknologi Augmented Reality." Data Manajemen Dan Teknologi Informasi (DASI) 18 (3): 49-54.

Hardiman, Agus. 2020. Kitab Sakti Music Creator. Jakarta Utara: Sonica Musik Internasional.

Huber, David Miles, and Robert Runstein. 2013. Modern Recording Techniques. Routledge.

Kurniawanto, Andhika, Indra Aji Sulistijono, and Citra Kusuma W. 2011. “Belajar Gamelan Jawa Menggunakan Platform IOS." Belajar Gamelan Menggunakan Platform IOS.

Maulana, Wisnu Ahmad, and Murinto Kusno. 2017. "Media Informasi Interaktif Teknik Pukulan Pada Kendang Sunda Berbasis Multimedia." Buffer Informatika 1 (1). https://doi.org/10.25134/buffer.v1i1.579.

Pramanta, Febyan Dimas, Abdur Rohman, and Moh Rizky Kurniawan. 2017. “Aplikasi Pembelajaran Alat Musik Daerah Gamelan Jawa Berbasis Teknologi Realsense." SENTIA 2017 9.

Pramudi, Y Tyas Catur, and Fikri Budiman. 2010. “Desain Virtual Gamelan Jawa Sebagai Media Pembelajaran." In Seminar Nasional Aplikasi Teknologi Informasi (SNATI).

Purwanto, Djoko. 2020. Gender Barung: Perspektif Organologi, Teknik, Dan Fungsi Dalam Karawitan Gaya Surakarta. 1st ed. Surakarta: ISI Press.

Raharja, Budi. 2019. "Pembelajaran Karawitan Jawa Tingkat Dasar Berbasis Multimedia Dalam Blended Learning." Resital Jurnal Seni Pertunjukan 20 (3): 176-88. https://doi.org/https://doi.org/10.24821/resital.v20i3.3842.

Roekmana, Giri Mustika, Fuja Siti Fujiawati, Rian Permana, and Dedi Hermansyah. 2020. “Aplikasi Mobile Apps Gamelan Untuk Pembelajaran Seni.” JPKS (Jurnal Pendidikan Dan Kajian Seni) 5 (2).

Santosa, Iwan Budi. 2021. "IImajiner Ruang Kepala Dalam Rekaman Gamelan Agêng Dengan Teknik Stereofonik." Acintya Jurnal Penelitian Seni Budaya 12 (2): 148-57. https://doi.org/10.33153/acy.v12i2.3579.

Savage, Steve. 2011. The Art of Digital Audio Recording: A Practical Guide For Home And Studio. Oxford University Press.

Shchugorev, V, V Khromatov, A Shchugorev, and L Sapunova. 2020. “Innovative Technologies in the Estimation of Oscillation Frequencies of Composite Structures with the Use of Audio 
Recording Equipment in the Laboratory of Dinamics and Strength of Machines." In $2020 \mathrm{~V}$ International Conference on Information Technologies in Engineering Education ( Inforino ), 1-5. https://doi.org/10.1109/Inforino48376.2020.9111851.

Sugiyono. 2009. Metode Penelitian Kuantitatif, Kualitatif Dan RED. Bandung: Alfabeta.

Sulistiono, Muhammad. 2019. "Implementasi Hybrid Learning Menggunakan Aplikasi Edmodo Pada Matakuliah Metode Penelitian Kualitatif." ElementerIs: Jurnal Ilmiah Pendidikan Dasar Islam 1 (1): 57-67.

Sumerjana, Ketut. 2019. "Pembelajaran Elecktronic Digital Music (Edm) Di Era-Milenial Pada Revolusi Industri 4.0." In Seminar Nasional Fakultas Seni Pertunjukan, 139-48.

Supanggah, Rahayu. 2002. Bothekan Karawitan I. Surakarta: Masyarakat Seni Pertunjukan Indonesia (MSPI).

Susila, I Putu Nata, I Gede Mahendra Darmawiguna, and I Made Gede Sunarya. 2015. "Pengembangan Aplikasi Gamelan Selonding Berbasis Android." KARMAPATI (Kumpulan Artikel Mahasiswa Pendidikan Teknik Informatika) 4 (2): 82-91.

Wahyono, Urip. 2017. “Produksi Rekaman Karawitan RRI Yogyakarta Sebagai Bentuk Pelestarian Budaya." Jurnal Warna 1 (1): 95-116.

\section{Webtografi}

Video "Membuat Studio Rekaman di Rumah \& Cara Pasang Alat-alatnya" di kanal youtube ArtSonica https://www.youtube.com/watch?v=qKOBzr2rjNw.

Video "Tutorial Focusrite 2i2 3 ${ }^{\text {rd }}$ Gen-Rekaman di HP, Cover Lagu Home Recording" di kanal youtube Laiqul https://www.youtube.com/watch?v=sgYrxiMmlu8.

Video “I.M. Harjito- Tutorial Gender Ladrang Pangkur” di kanal youtube Sumunar MN https://www.youtube.com/watch?v=2Q 9C2CJAJQ,

Video dengan judul “Darsono Hadiraharjo-Tutorial Rebab Gendhing Gambirsawit” di kanal youtube Sumunar MN https:/ / www.youtube.com/watch?v=UBmDAJcoxVw.

https:/ / recordingstudio101.com/home-recording-studio-essentials/ )

https://www.zealmusik.com/2019/08/20/jenis-kabel-audio/

\section{Daftar Narasumber}

Aloysious Suwardi, 72 Tahun, Pengajar di Jurusan Karawitan ISI Surakarta

Bambang Sosodoro, 39 Tahun, Pengajar di Jurusan Karawitan ISI Surakarta

Merwan Ardhi Nugroho, 30 Tahun, Teknisi Audio, Founder Airy Audio Society

Wahyu Thoyyib Pambayun (Pemanfaatan Audio Recording Equipment Dalam Pembelajaran Praktik Instrumen Rebab, Kendang Dan Gender) 